\title{
OCCURRENCE OF MELAMPYRUM CRISTATUM L. IN DĘBNO UPON WARTA (WIELKOPOLSKA, POLAND)
}

\author{
Aneta Czarna, Mągorzata Klimko, Magdalena WawrzyńsKa
}

\begin{abstract}
A. Czarna, M. Klimko, Department of Botany, Poznań University of Life Sciences, Wojska Polskiego 71 C, 60-625 Poznań, Poland, e-mail: czarna@up.poznan.pl; klim@up.poznan.pl

M. Wawrzyńska, Klaudyna Potocka High School, Zmartwychstańców 10, 61-501 Poznań, Poland, e-mail: wawrzynska@poczta.onet.pl
\end{abstract}

(Received: April 22, 2014. Accepted: July 14, 2014)

\begin{abstract}
AвSTRACT. The paper characterises a new locality of Melampyrum cristatum identified in Dębno upon Warta (Wielkopolska region, Poland). Its ecological conditions are presented, along with the size of the population, phytosociological affiliation, as well as a characteristics of the species focusing on new traits of seed sculpture.
\end{abstract}

KEY WORDS: Melampyrum cristatum, Scrophulariaceae, seeds, SEM, new localities, Wielkopolska

\section{INTRODUCTION}

Melampyrum cristatum L. from the broomrape family (Orobanchaceae), formerly included in the figwort family (Scrophulariaceae sensu lato), is a hemiparasitic annual plant. It flowers from May to September (JASIEWICZ 1963).

Throughout Poland Melampyrum cristatum was considered to be an extinct species (Ex - extinct and missing) (ZARZYCKI \& SZELĄG 2006), while previously it had been assigned to the category of rare species (R) (JASIEWICZ 1981, ZARZYCKI \& SZELĄG 1992). In the Wielkopolska region it was classified as a declining taxon (E - declining) (ŻuKowsKI \& JACKOWIAK 1995), whereas according to the latest classification - to the endangered (En) category (JACKOWIAK ET AL. 2007). To date a total of 27 ATPol squares of $10 \times 10 \mathrm{~km}$ have been reported from the Wielkopolska region (ZAJĄC \& ZajĄC, eds. 2001, STACHNOWICZ 2013).

The new previously unknown, locality for the Wielkopolska region was found for the first time in 2007, while in 2013 detailed observations were conducted at the Warta River approx. $0.5 \mathrm{~km}$ north-east from the ferry terminal in the village of Dębno upon Warta, the Nowe Miasto upon Warta commune, the Środa Wielkopolska county, the Wielkopolskie voivodeship. The locality has already been included in a floristic study concerning central Wielkopolska (CZARNA 2009). It is situated in the ATPol square CD32 within the Żerkowsko-Czeszewski Landscape Park, as well as the Natura 2000 area of Lasy Żerkowsko-Czeszewskie PHL300053.

The aim of this study was to identify a subspecies in the newly reported locality and to provide its morphological characteristics.

\section{MATERIAL AND METHODS}

Some measurements for the morphological characteristics were recorded on site so as not to destroy specimens. Ripe seeds were collected twice, in 2007 and 2013, and deposited at the carpological collection of the Department of Botany, the Poznań University of Life Sciences (POZNB). The SEM micrographs were taken with a Zeiss EVO 40 microscope at the Electron Microscopy Laboratory, the Faculty of Biology, the Adam Mickiewicz University of Poznań. Prior to observations, the prepared material was sputtered with gold using an SCB 050 ion sputter. In the micromorphological description of seed surface texture, the following concepts were used: arrangement of epidermal cells, primary sculpture and secondary sculpture (BARTHLOTT 1984). 


\section{RESULTS}

\section{A. CHARACTERISTICS OF THE NEW LOCALITY OF MELAMPYRUM CRISTATUM}

The locality at Dębno upon Warta is situated in an active floodplain, composed from alluvial soils. It is located approx. $50 \mathrm{~m}$ west of a railway bridge on the Warta River and approx. $12 \mathrm{~m}$ south of the Warta bank (Fig. 1).

The most numerous of the three clusters is situated in a grassy glade of $20 \times 20 \mathrm{~m}$ with scarce shrubs, at a distance of approx. $7 \mathrm{~m}$ from the Warta river channel margin. It is surrounded with forest on all sides and a path leading to the Warta crosses it in the centre. The discussed species is growing here in a tall grass and herb community of Calamagrostietum epigeji Juraszek 1928, classified to class Epilobietea angustifolii R. Tx. et Presg 1950. The following plant species were recorded as concurrent (the degree of cover in a 7-point Braun-Blanquet scale is given in parentheses, the relevé $(20 \times 20 \mathrm{~m})$ was made on 20.07.2013, layer cover a $-10 \%, b-15 \%, c-95 \%)$.
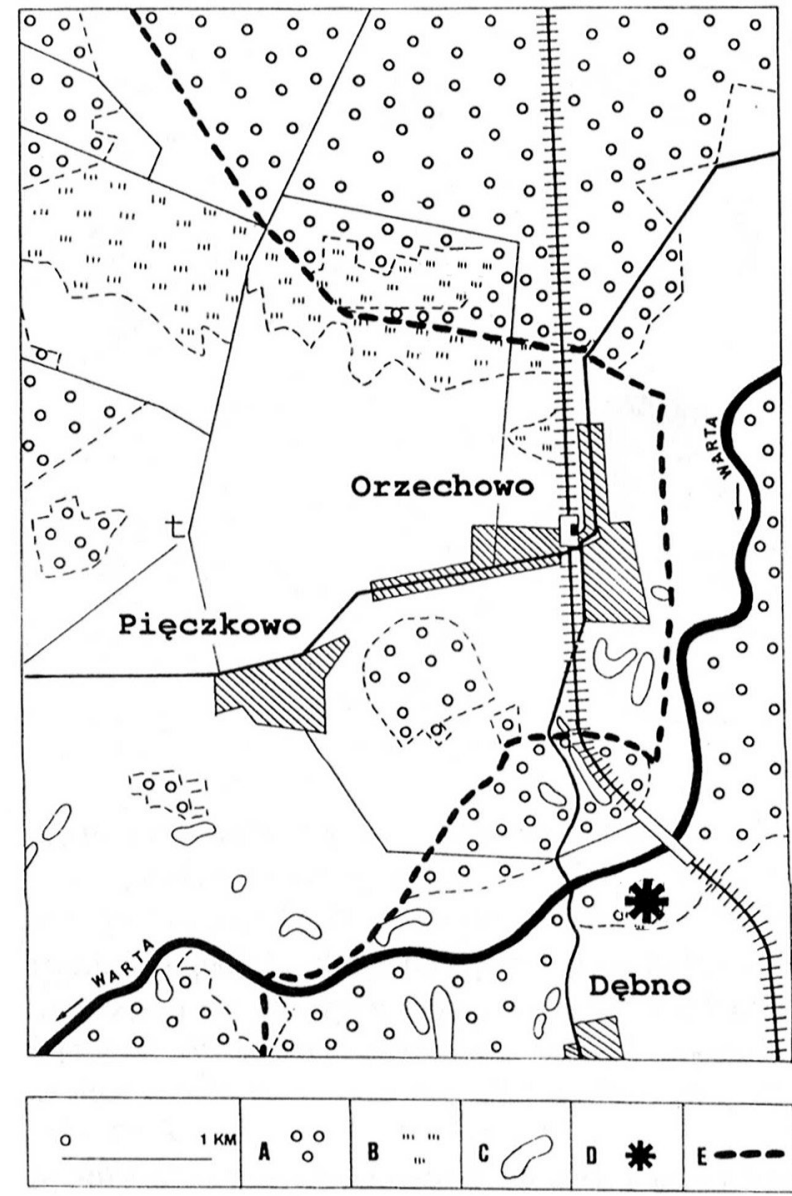

Fig. 1. Location of the new Melampyrum cristatum L. locality near Dębno upon Warta (the Wielkopolskie voivodeship). A - forests, B - meadows, C - old river-beds, D - locality of Melampyrum cristatum, E - western boundary of the Żerków-Czeszewo Landscape Park
Woody layer: Quercus robur (1). Shrub layer: Populus alba (1), Acer campestre (+), Betula pendula (+), Cornus sanguinea $(+)$, Crataegus monogyna $(+)$, Fraxinus excelsior $(+)$, Ligustrum vulgare $(+)$, Malus oxysepala $(+)$, Padus avium $(+)$, Prunus spinosa $(+)$, Populus alba $(+)$, Quercus petrea $(+), Q$. robur $(+)$, Rhamnus cathartica $(+)$, Rosa canina $(+)$, Salix purpurea $(+)$. The herbaceous layer: Calamagrostis epigejos (4), Melampyrum cristatum (2), Agrostis capillaris (1), Equisetum arvense (1), Sedum sexangulare (1), Agrimonia procera (+), Dactylis glomerata $(+)$, Epipactis helleborine $(+)$, Festuca rubra (+), Galium aparine (+), Glechoma hederacea $(+)$, Hypericum perforatum $(+)$, Rubus caesius $(+)$, Rumex acetosa $(+)$, Vicia cracca $(+)$, Allium oleraceum $(\mathrm{r})$, A. vineale (r), Asparagus officinalis (r), Calystegia sepium (r), Chaerophyllum temulum ( $\mathrm{r}$ ), Cirsium arvense (r), Dryopteris carthusiana (r), Elymus repens (r), Fallopia dumetorum (r), Galium mollugo ( $\mathrm{r}$ ), Geranium robertianum (r), Pimpinella saxifraga (r), Rumex acetosella (r), Scrophularia nodosa (r), Scutellaria hastifolia (r), Stachys palustris (r), Tanacetum vulgare (r), Torylis japonica (r), Urtica dioica (r), Veronica chamaedrys (r), Veronica longifolia (r), Vicia cracca (r), Viola canina (r).

The second cluster of approx. 55 specimens is located at a distance of approx. $100 \mathrm{~m}$ to the west and is found in a small belt of a forest directly at the Warta river channel margin in a tall grass and herb community Calamagrostietum epigeji Juraszek 1928 under a canopy of trees Quercus robur and Pinus sylvestris. The relevé was prepared on 20.07.2013 in an area of $20 \times$ $20 \mathrm{~m}$, ground cover $\mathrm{a}-50 \%, \mathrm{~b}-15 \%, \mathrm{c}-85 \%$. The following species were recorded among concurrent species - the woody layer: Quercus robur (3), Pinus sylvestris (1). The shrub layer: Crataegus monogyna (1), Acer campestre (+), Frangula alnus (+), Humulus lupulus $(+)$, Rhamnus catartica $(+)$, Rosa canina $(+)$, Ulmus campestris $(+)$. The herbaceous layer: Calamagrostis epigejos (3), Convallaria majalis (1), Glechoma hederacea (1), Melampyrum cristatum (1), Chaerophyllum temulum (+), Dactylis polygama (+), Lysimachia nummularia $(+)$, Poa angustifolia $(+)$, Rhamnus cathartica $(+)$, Rubus caesius (+), Rumex thyrsiflorus (+), Veronica chamaedrys (+), Achillea salicifolia (r), Agrimonia procera (r), Arrhenatherum elatius (r), Carex sylvatica (r), Festuca gigantea $(\mathrm{r})$, Epipactis helleborine ( $\mathrm{r})$, Galium boreale (r), Geranium robertianum (r), Geum urbanum (r), Pimpinella nigra (r), Poa palustris (r), Silene tatarica $(\mathrm{r})$, Poa nemoralis $(\mathrm{r})$, Tanacetum vulgare $(\mathrm{r})$, Torilis japonica $(\mathrm{r})$, Veronica longifolia $(r)$.

A third cluster of 15 Melampyrum cristatum specimens was recorded in the communities of Potentillo albae-Quercetum Libb. 1933 and Calamagrostietum epigeji Juraszek 1928 under the canopy of Quercus robur. It was situated $50 \mathrm{~m}$ to the east from the first cluster and approx. $6 \mathrm{~m}$ from the Warta channel margin.

All the three clusters were found (2007) and they jointly comprised approx. 1650 flowering shoots, with a similar number recorded in 2013 . The greatest 
threat for this population may be posed by flood and tourists or fishermen bivouacking in the glade.

In 2001 a new locality of Melampyrum cristatum was also found, which was situated approx. $300 \mathrm{~m}$ north from Ciążeń, the Lądek commune, the Słupca county, the Wielkopolskie voivodeship (CZARNA 2009) and approx. $28 \mathrm{~km}$ east of the locality being described. It was recorded in the ATPol square CD24. In 2007 attempts were made to find it again, but it was stated that that population had died out. Further search attempts may be undertaken in the immediate vicinity and its environs.

\section{B. MORPHOLOGICAL CHARACTERISTICS OF MELAMPYRUM CRISTATUM IN THE NEW LOCALITY}

Four subspecies were distinguished within Melampyrum cristatum (OBERSDOFER 1983), of which three were recorded in Poland, i.e. M. c. subsp. solstitiale (Ronn.) Ronn., M. c. subsp. ronnigeri (Poeverl.) Ronn. and M. c. subsp. cristatum (RUTKOWsKi 1998). In the locality at Dębno upon Warta all the specimens belonged to the transitional subspecies between subsp. solstitiale (Ronn.) Ronn. and subsp. cristatum.
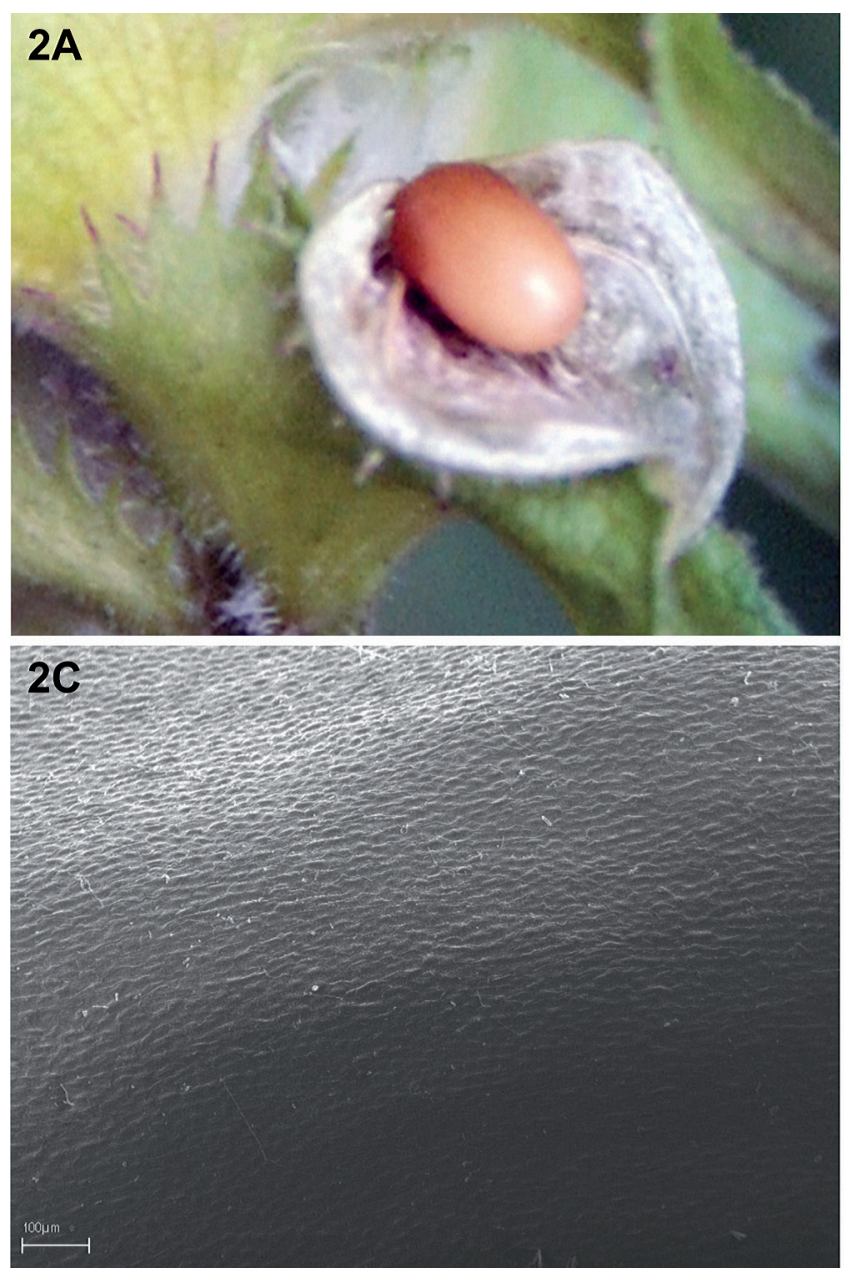

The observed specimens of Melampyrum cristatum grew up to $15-40 \mathrm{~cm}$ in height. Assimilating leaves were most typically oblong-lanceolate or oblong from 2 to $6.5 \mathrm{~cm}$ long and 2 to $6 \mathrm{~mm}$ wide. The inflorescence starts at the fourth or fifth node. It is a four-edged spike of 1 up to $5 \mathrm{~cm}$ in length. Bracts imbricate in four rows, obcordate or obovate or reniform, folded mid-length upwards along the midvein, spiny and ciliately toothed - crested (from which the common name of the plant was derived), light purple or crimson coloured. Two specimens with white bracts were also observed. Bracts of 2.0 up to 6.5 $\mathrm{cm}$ in length and from 3 to $7 \mathrm{~mm}$ in width, corolla up to $19 \mathrm{~mm}$ long, and flowers were most typically multicoloured: yellow at the tip, white in the middle and purple at the base. Fruit were obovate, slightly falcate, from 7 to $12 \mathrm{~mm}$ long, at the tip cuspidate, on the surface scarcely pubescent and ciliate on the margins. Seeds were from 2.81 to $3.75 \mathrm{~mm}$ long and from 1.31 to $1.69 \mathrm{~mm}$ wide (Fig. $2 \mathrm{~B}$ ), orange-brown with a long elaiosome (Fig. $2 \mathrm{~A}$ ). The surface characters of Melampyrum cristatum seeds are described here, in more detail, and they have micromorphological features that have not been reported before.
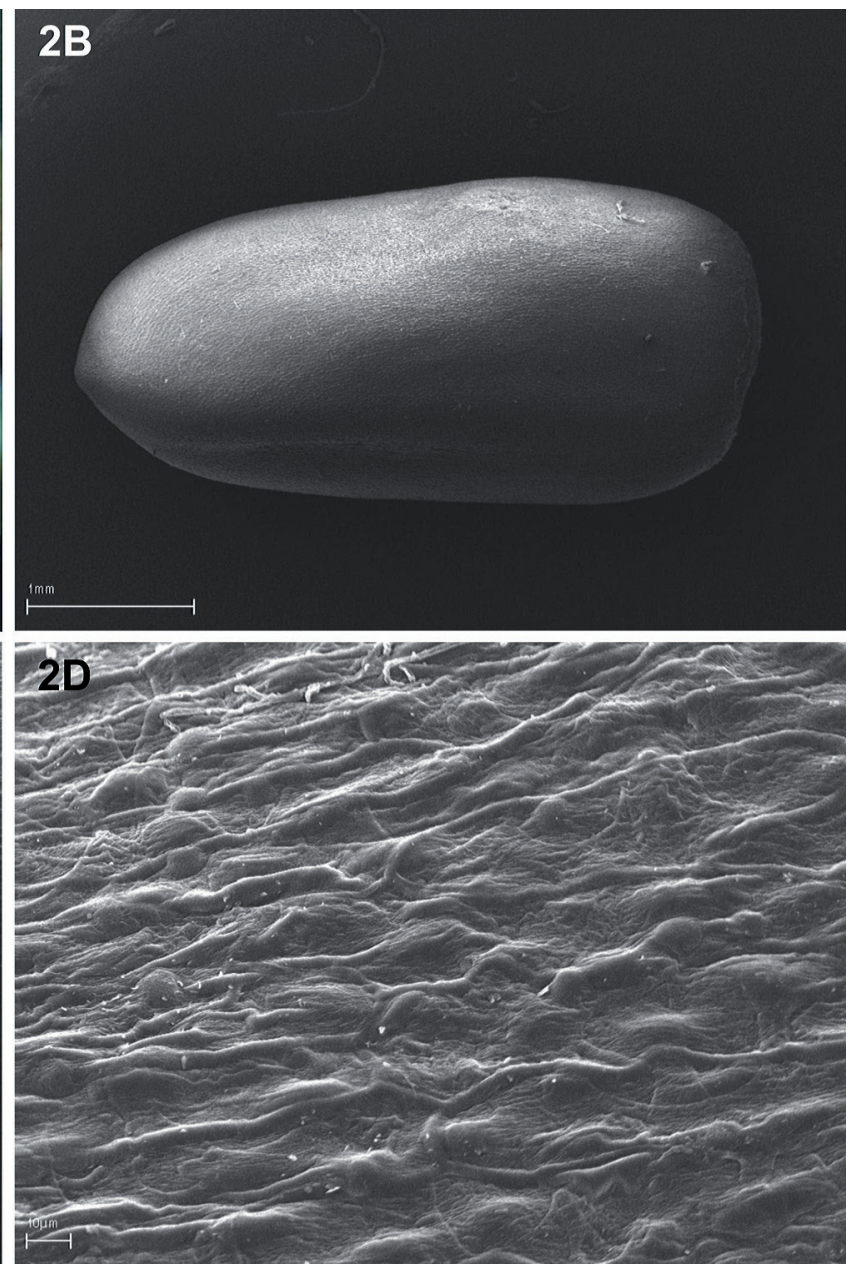

Fig. 2. Fruit and seeds of Melampyrum cristatum L. in Dębno upon Warta. A - a bursting sac with seed, B - seed shape $\times 75$, C - seed sculpture $\times 300$, D - seed sculpture $\times 2000$ 
SEM observations show that the seeds have a very irregular surface topography with differently exposed epidermal cell walls. The surface was made by raised anticlinal boundaries. Most anticlinal walls were unevenly thickened, slightly undulated, and with striated secondary sculpture. (Fig. $2 \mathrm{C}$ and D).

\section{CONCLUSION}

The reported locality of Melampyrum cristatum shows a very high attachment to the Warta river valley, similarly as in most localities reported in Poland (ZAJĄC \& ZAJĄC, eds 2001). The specimens belong to a transitional subspecies between subsp. solstitiale and subsp. cristatum.

We propose to retain the original classification of the discussed species as Endangered (EN) for the Wielkopolska region, as it was previously reported by JACKOWIAK et al. (2007), while for Poland it should be changed to CR (Critically Endangered).

In view of the rare occurrence of Melampyrum cristatum in the Wielkopolska region it is justified to undertake tangible measures in the next vegetation seasons in order to protect the localities in Dębno upon Warta and characterise them in detail, determining habitat conditions, phenology, propagation, spatial structure, density, number of specimens, production of flowers and seeds, as well as germinability and the first development phases, parasitism and the degree of threat.

The locality described above is monitored by nature wardens of the Żerków-Czeszewo Landscape Park (MASZTALERZ 2013).

\section{REFERENCES}

Barthlott W. (1984): Microstructural features of seed surface. In: V.H. Heywood, D.M. Moore (eds.). Current concepts in plant taxonomy. Academic Press, London.

CZARnA A. (2009): Rośliny naczyniowe środkowej Wielkopolski. Wyd. Uniwersytetu Przyrodniczego, Poznań.

Jackowiak B., Celka Z., Chmiel J., Latowski K., ŻuKOWSKI W. (2007): Red list of vascular flora of Wielkopolska (Polska). Biodiversity Research and Conservation 5-8: 95-127.
JASIEWICZ A. (1963): Podrodzina: Rhinanthoideae. In: B. PAwŁowski (ed.). Flora Polska. Rośliny naczyniowe Polski i Ziem Ościennych. Vol. 10. PWN, Warszawa-Kraków, 339-385.

JASIEwICZ A. (1981): Wykaz roślin rzadkich i zagrożonych flory polskiej. Fragmenta Floristica et Geobotanica 27(3): 401-414.

Masztalerz M. (2013): Pszeniec grzebieniasty (Melampyrum cristatum L.) w Żerkowsko-Czeszewskim Parku Krajobrazowym. Biuletyn Parków Krajobrazowych Wielkopolski 19: 153-155.

Obersdofer E. (1983): Pflanzensoziologische Exkursionsflora. Verlag Eugen Ulmer, Stuttgart.

Rutкowsкi K. (1998): Klucz do oznacznaczania roślin naczyniowych Polski niżowej. Wydawnictwo Naukowe PWN, Warszawa.

StaCHNOWICZ W. (2013): Melampyrum cristatum L. - a rare river corridor plant in Wielkopolska and Poland. Biodiversity Research and Conservation 32: $29-44$.

Zając A., Zając M., eds (2001): Atlas rozmieszczenia roślin naczyniowych $\mathrm{w}$ Polsce. [Distribution atlas of vascular plants in Poland]. Pracownia Chorologii Komputerowej Instytutu Botaniki Uniwersytetu Jagiellońskiego, Kraków.

ZARZYCKI K, SZELĄG Z. (1992): Czerwona lista roślin naczyniowych zagrożonych $\mathrm{w}$ Polsce In: K. ZarZycki, W. Wojewoda, Z. HeInRICH (eds). Lista roślin zagrożonych $\mathrm{w}$ Polsce [The list of threatened plants in Poland]. Instytut Botaniki im. W. Szafera, Polska Akademia Nauk, Kraków: 87-98.

ZARZYCKI K., SzeląG Z. (2006): Red list of vascular plants in Poland. Czerwona lista roślin naczyniowych w Polsce. In: Z. Mirek, K. Zarzycki, W. WoJEWODA, Z. SzeląG (eds) Red list of plants and fungi in Poland. Czerwona lista roślin i grzybów Polski. Władysław Szafer Institute of Botany, Polish Academy of Sciences, Kraków.

ŻuKowsKi W., JACKowiaK B. (1995): Lista roślin naczyniowych ginących i zagrożonych na Pomorzu Zachodnim i w Wielkopolsce. In: W. Żukowski, B. JACKOWIAK (eds). Ginące i zagrożone rośliny naczyniowe Pomorza Zachodniego i Wielkopolski. Prace Zakładu Taksonomii Roślin UAM 3: 9-99. Bogucki Wydawnictwo Naukowe, Poznań. 